J. MED. MICROBIOL---VOL. 20 (1985), 33-38

(1985 The Pathological Society of Great Britain and Ireland

\title{
SERUM FACTORS FOR OPSONISATION OF NON-TYPABLE HAEMOPHILUS INFLUENZAE
}

\author{
A. M. L. Lever, J. Gross ANd A. D. B. Webster \\ Division of Immunological Medicine, Clinical Research Centre, Harrow, Middlesex \\ HAI $3 U J$
}

\begin{abstract}
SUmmary. Neutrophil chemiluminescence was used to assess the opsonins required for phagocytosis of non-typable Haemophilus influen$z a e$ isolated from sputum samples of patients with hypogammaglobulinaemia. Immunoglobulin was the major opsonin, whereas complement was relatively unimportant. Evidence was found for a heat-labile opsonin other than complement that enhanced phagocytosis of these organisms. Tuftsin was shown to aid phagocytosis of $H$. influenzae without triggering chemiluminesence.
\end{abstract}

\section{INTRODUCTION}

Patients with late onset (common variable) hypogammaglobulinaemia are prone to chronic bronchitis which may eventually lead to bronchiectasis (Asherson and Webster, 1980). Non-typable Haemophilus influenzae (NTHI) are commonly isolated from the sputum of these patients during acute exacerbations and in the more chronic phase. The observation that their chest disease usually improves after gammaglobulin therapy suggests that antibody plays a major role in the control of NTHI infection (MRC Report, 1971). Specific antibodies can inhibit the growth (Tully et al., 1983) or trigger complement lysis of certain organisms, but another important function is to opsonise bacteria for phagocytosis and ultimate destruction by neutrophils. Using a neutrophil chemiluminescence assay, we have investigated the critical serum factors required to opsonise NTHI in vitro, making use of various putative opsonins and sera deficient in immunoglobulin or complement.

\section{Materials AND METHODS}

Organisms. Sputum samples from hypogammaglobulinaemic patients were collected during exacerbations and remission phases of their bronchitis; and, from the first 10 samples which grew $H$. influenzae, the isolates were maintained on chocolate-agar slopes. These were examined for iridescence on Levinthal's medium, and tested for agglutination by commercial antisera (Burroughs Wellcome, types $\mathrm{a}-\mathrm{f}$ ) on glass slides. Eight of the 10 isolates were non-typable and were used in our experiments.

Opsonic factors. Serum from healthy subjects was separated within $30 \mathrm{~min}$ of venepuncture and stored at $-70^{\circ} \mathrm{C}$ before use.

Pooled human gammaglobulin was obtained from the Blood Products Laboratory (BPL), Elstree, Herts. This is a new preparation for intravenous use which is currently under clinical 
trial. It was used at a final concentration of $10 \mathrm{mg} / \mathrm{ml}$ which approximates to the physiological level.

Fibronectin was a gift from Dr Brown of the BPL. It was free of other proteins and passed through a $0.2 \mu \mathrm{m}$ filter. It was used at a final concentration of $140 \mu \mathrm{g} / \mathrm{ml}$, approximately the physiological level. Tuftsin was obtained from Sigma Pharmaceuticals and was used at a final concentration of $100 \mu \mathrm{g} / \mathrm{ml}$.

"Heat inactivation" of serum was performed by heating the sample at $56^{\circ} \mathrm{C}$ for $30 \mathrm{~min}$. The alternative complement pathway was inactivated by heating at $40^{\circ} \mathrm{C}$ for $15 \mathrm{~min}$ (Thompson, 1981). Inactivation of either the whole complement pathway or the alternative pathway was confirmed by haemolytic plate assays (Martin and Lachmann, 1977).

Absorption of serum and gammaglobulin solutions with NTHI was performed with a pellet of NTHI (c. $5 \times 10^{10}$ organisms) previously washed in phosphate buffered saline (PBS). This was suspended in $1 \mathrm{ml}$ of serum or gammaglobulin at $4^{\circ} \mathrm{C}$ for $24 \mathrm{~h}$. The suspension was centrifuged at $4^{\circ} \mathrm{C}$ and the clear supernate removed and used.

Luminometer medium. Hanks's buffered salt solution (HBSS) without phenol-red was further buffered with $2 \mathrm{ml}$ of Hepes (N-2-Hydroxyethyl piperazine $\mathrm{N}^{\prime}$-2-ethanesulphonic acid-Sigma Chemical Co. Ltd, St Louis, MI) per $100 \mathrm{ml}$ of HBSS, and adjusted to $\mathrm{pH} 7.4$ with sodium hydroxide; $17.7 \mathrm{mg}$ of Luminol (5-Amino-2,3 dihydro-1,4 phthalazinedione-Sigma) was dissolved in $10 \mathrm{ml}$ of dimethyl sulphoxide (DMSO) and added to the buffered HBSS at 1 in 1000 final concentration of Luminol.

Chemiluminescence assay. Neutrophils were obtained from healthy subjects and hypogammaglobulinaemic patients in the following manner. Subjects were exercised to increase the yield by mobilising the marginating pool of neutrophils, and $20 \mathrm{ml}$ of blood was obtained by venepuncture into tubes containing heparin $(10 \mathrm{u} / \mathrm{ml})$. The red cells were sedimented by mixing the blood with $4 \mathrm{ml}$ of Dextran 150 (Fisons Ltd) and leaving for $30 \mathrm{~min}$ at room temperature. The leukocyte-rich supernate was then removed and centrifuged at $120 \mathrm{~g}$ for $10 \mathrm{~min}$. The supernate was removed and the cells were subjected to hypotonic lysis with $5 \mathrm{ml}$ of distilled water for $30 \mathrm{~s}$ to remove residual erythrocytes, followed by addition of $5 \mathrm{ml}$ of $1.8 \%$ saline to restore isotonicity. PBS, $10 \mathrm{ml}$, was added and the suspension centrifuged at $85 \mathrm{~g}$ for $10 \mathrm{~min}$. The cells were then washed in sterile PBS and resuspended in luminometer medium. This gave a suspension of $>90 \%$ neutrophils which were counted in a Neubauer counting chamber and adjusted to a final concentration of $2 \times 10^{6} / \mathrm{ml}$.

Volumes $(1 \mathrm{ml})$ of the neutrophil suspension were prewarmed to $37^{\circ} \mathrm{C}$ for $15 \mathrm{~min}$ before use and $100 \mu \mathrm{l}$ of NTHI suspension $\left(2 \times 10^{9} / \mathrm{ml}\right)$ in PBS was added to each sample in the presence of test opsonin or serum, or both. Chemiluminescence was measured in a luminometer (LKB Wallac) with an automatic stirrer at $37^{\circ} \mathrm{C}$. Luminescence was plotted against time, and the slopes and peak values of the resulting graphs were compared. Reproducibility within an experiment was good using this method.

Electronmicrographs. For each experimental condition, representative tubes were taken 10 min after addition of NTHI and the reaction mixture was fixed with glutaraldehyde $3 \%$ in $0.1 \mathrm{M}$ cacodylate buffer. Specimens were then post-fixed with osmium tetroxide $1 \%$, dehydrated with acetone, and embedded in spurr resin. Sections were stained with uranyl acetate and lead citrate, and viewed on a Jeol JEM 1200 EX electronmicroscope.

\section{RESULTS}

Fig. 1 shows a marked increase in chemiluminescence when normal serum was added to normal neutrophils and NTHI. This does not appear to be mediated through activation of complement, since C2-deficient serum and Factor-B-inactivated serum both gave a similar response. These experiments were repeated three times with the C2-deficient serum, and twice with Factor-B-inactivated serum, with neutrophils from different healthy donors. The same phenomenon was observed on each occasion. However, after heat inactivation, both normal serum (four separate experiments with 


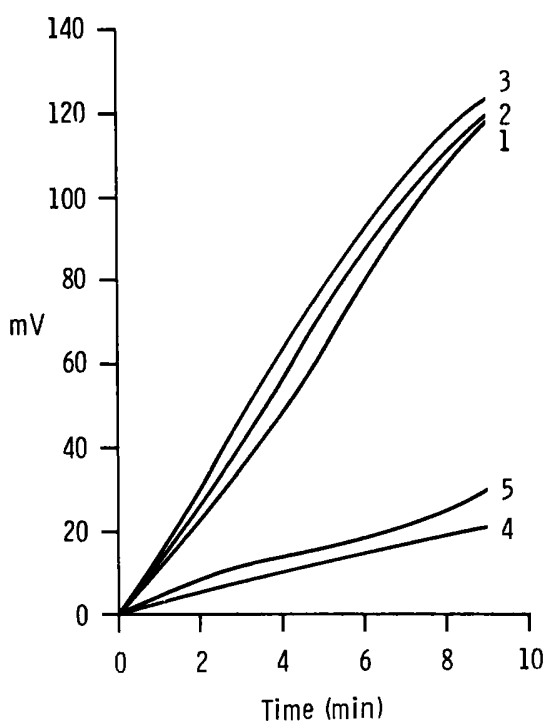

FIG. 1 .

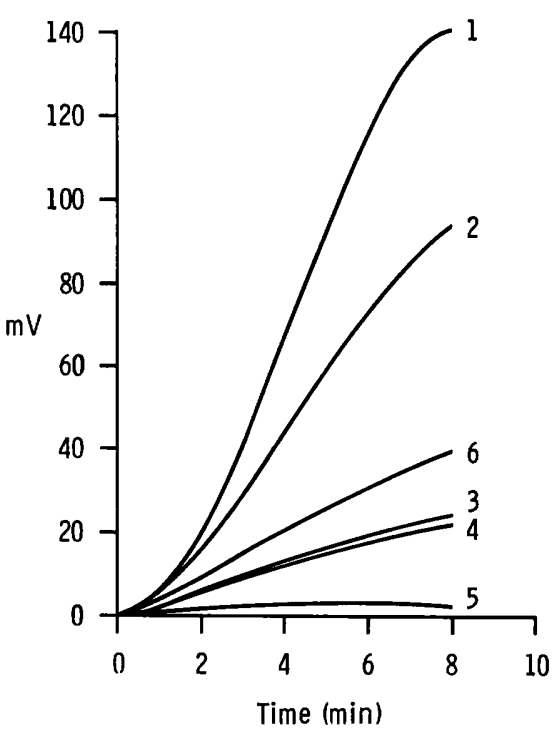

FIG. 2.

Fig. 1.-Effect of complement-deficiency and heat-inactivation of serum on chemiluminescence of normal neutrophils with non-typable $H$. influenzae. 1 -normal serum $(\operatorname{IgG} 17.8 \mathrm{~g} / \mathrm{L}, \operatorname{IgA} 4.2 \mathrm{~g} / \mathrm{L}, \operatorname{IgM} 2.0 \mathrm{~g} / \mathrm{L})$; $2-\mathrm{C}_{2}$-deficient serum (IgG 6.5 g/L, IgA $1.5 \mathrm{~g} / \mathrm{L}$, IgM $6.4 \mathrm{~g} / \mathrm{L}$ ); 3-normal serum (1) with Factor B inactivated $\left(40^{\circ} \mathrm{C}, 15 \mathrm{~min}\right) ; 4$ - normal serum (1) "heat inactivated" $\left(56^{\circ} \mathrm{C}, 30 \mathrm{~min}\right) ; 5-\mathrm{C}_{2}$-deficient serum (2) "heat inactivated" $\left(56^{\circ} \mathrm{C}, 30 \mathrm{~min}\right)$. Similar results were obtained in two experiments.

Fig. 2.-Effect of pooled gammaglobulin on chemiluminescence of normal neutrophils with non-typable $H$. influenzae (NTHI). 1-normal serum (Ig levels as fig. 1);2-pooled gammaglobulin ( $\operatorname{lgG} 10 \mathrm{~g} / \mathrm{L}$ ); 3-normal serum (1) after preabsorption with NTHI; 4-pooled gammaglobulin (2) after preabsorption with NTHI; 5 - pooled gammaglobulin (2) alone, no bacteria present; 6 -hypogammaglobulinaemic serum (IgG $2.0 \mathrm{~g} / \mathrm{L}$, $\operatorname{IgA}<0.1 \mathrm{~g} / \mathrm{L}, \operatorname{IgM}<0.1 \mathrm{~g} / \mathrm{L}$ ). Similar results were obtained in two experiments.

identical conditions) and C2-deficient serum (two experiments) gave a very poor response, suggesting that a non-complement heat-labile factor is required.

Fig. 2 shows that pooled gammaglobulin induced chemiluminescence from neutrophils in the presence of NTHI. This was consistent in many different experiments in which neutrophils from different donors and various commercially available immunoglobulin concentrates were used. The activity was removed by absorption of the pooled IgG with NTHI, suggesting that the relevant factor is antibody. Hypogammaglobulinaemic serum gave a poor response.

The table shows different experiments with the neutrophils from one healthy subject, with various isolates of NTHI. There was a consistent increase in chemiluminescence when pooled gammaglobulin was added to hypogammaglobulinaemic serum. Likewise, pooled gammaglobulin increased the chemiluminescence of neutrophils from a hypogammaglobulinaemic patient, although the levels of chemiluminescence of these neutrophils were much lower. The neutrophils from three other hypogammaglobulinaemic patients have been similarly tested with the NTHI-4 isolate in the presence of autologous hypogammaglobulinaemic serum. There was a clear trend for these neutrophils to produce relatively less chemiluminescence than that seen 
TABLE

Chemiluminescence of neutrophils with non-typable $H$. influenzae (NTHI)

\begin{tabular}{ccc}
\hline & Luminescence (mV at 5 min) of neutrophils in presence of \\
\cline { 2 - 3 } $\begin{array}{c}\text { Strain } \\
\text { of NTHI }\end{array}$ & $\begin{array}{c}\text { hypogammaglobulinaemic } \\
\text { serum* }\end{array}$ & $\begin{array}{c}\text { hypogammaglobulinaemic } \\
\text { serum* + gammaglobulin (BPL) }\end{array}$ \\
\hline & Neutrophils from one healthy subject $\dagger$ \\
1 & 35 & 80 \\
1 & 30 & 95 \\
2 & 50 & 100 \\
2 & 50 & 110 \\
3 & 70 & 140 \\
3 & 60 & 130 \\
4 & 30 & 90 \\
& & \\
1 & Neutrophils from one hypogammaglobulinaemic subject $\ddagger$ \\
2 & $2 \cdot 5$ & 25 \\
3 & 5 & 60 \\
4 & 10 & 50 \\
& 5 & 35
\end{tabular}

* Ig levels of serum: IgG $2.0 \mathrm{~g} / \mathrm{L}, \operatorname{IgA}<0.1 \mathrm{~g} / \mathrm{L}, \operatorname{IgM}<0.1 \mathrm{~g} / \mathrm{L}$.

$\dagger$ Similar values were obtained with neutrophils from four other healthy subjects.

¥ Similar values were obtained with neutrophils from three other hypogammaglobulinaemic subjects.
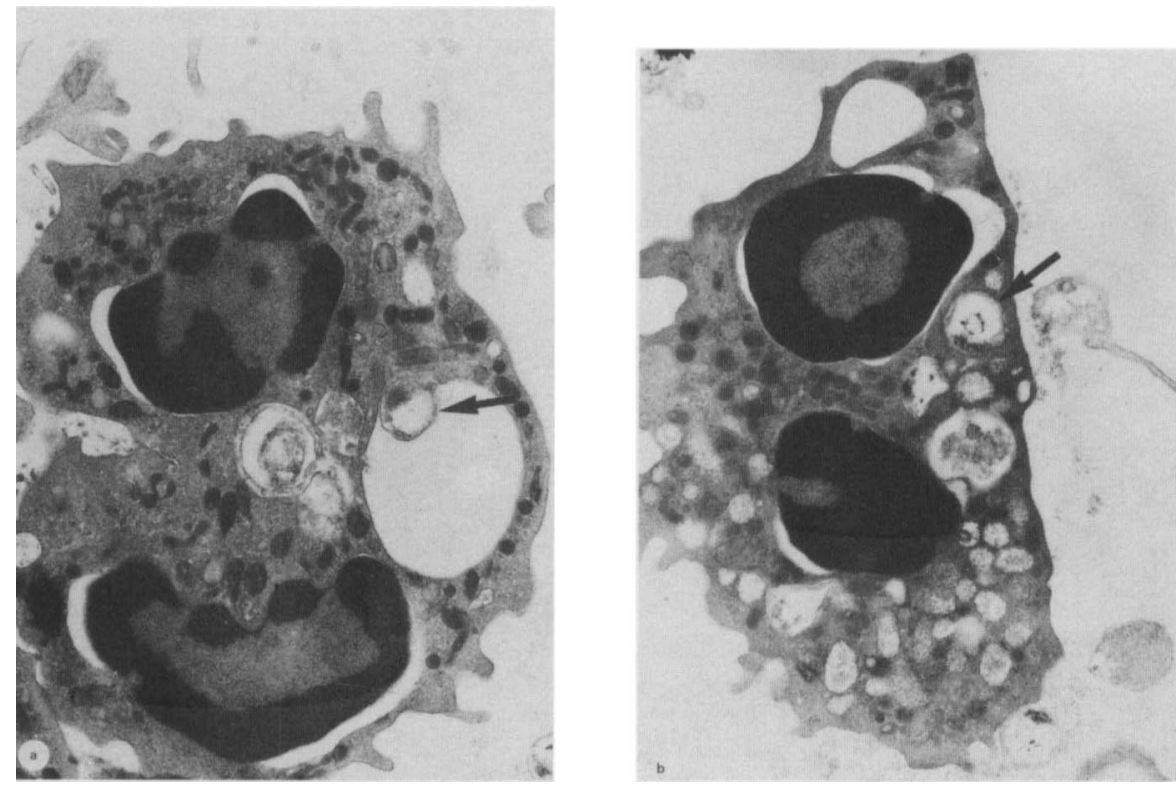

FIG. 3.-Phagocytosis of non-typable $H$. influenzae (NTHI): (a) with normal serum-arrow shows NTHI in phagocytic vacuole in neutrophil; $(b)$ with tuftsin-arrow shows NTHI in neutrophil with no vacuole formation $(\times 10000)$. 
with neutrophils from healthy subjects, although this was not subjected to statistical analysis as the experiments were not strictly comparable.

The addition of fibronectin and tuftsin produced no chemiluminescence in two separate experiments with NTHI strain 4 and normal neutrophils.

Electronmicrographs showed phagocytosis of organisms with serum or gammaglobulin and the organisms are seen in large phagocytic vacuoles (fig. $3 a$ ). In contrast, although there was some phagocytosis of organisms when tuftsin was used as an opsonin, the phagosomes failed to develop into large vacuoles (fig. $3 b$ ). No organisms were seen in cells in the absence of these opsonic factors or when fibronectin was used.

\section{Discussion}

There is clinical evidence that the severity and frequency of bronchitis in patients with primary hypogammaglobulinaemia improves on gammaglobulin therapy (MRC Report, 1971). Capsulated $H$. influenzae is sometimes isolated from the sputum of these patients although non-capsulated (non-typable) organisms are usually found. It could be argued that such bacteria lose their capsules during isolation but most investigators now concede that non-typable organisms can cause disease (Wallace et al., 1981); their importance in patients without a primary immunodeficiency has also been recently emphasized (Musher et al., 1983b). Clinical improvement after gammaglobulin-replacement therapy suggests that IgG antibody plays a major part in defence against non-typable $H$. influenzae (NTHI). This contrasts with other gram-negative organisms that are not so dependent on antibody for opsonisation (Horwitz, 1980) and that rarely cause disease in patients with hypogammaglobulinaemia (Asherson and Webster, 1980).

Using a chemiluminescence assay to analyse the opsonins for NTHI in serum, we have shown that IgG-concentrates are almost as efficient as whole serum. However the opsonic activity of serum is heat-labile and this is not due to loss of complement because serum from a patient with homozygous C2-deficiency and also Factor-B-depleted serum produce normal chemiluminescence. Hence neither the classical nor alternative complement pathways can be significantly involved. This heat-lability suggests that either some or all of the specific antibodies are rendered non-functional by heating or that there is a heat-labile 'third factor' opsonin as previously suggested (Musher et al., 1983a).

There is a strong impression that the neutrophils from hypogammaglobulinaemic patients produce relatively less chemiluminescence than neutrophils from normal subjects, when hypogammaglobulinaemic serum alone or with additional pooled gammaglobulin is used as an opsonin for NTHI. This is probably explained by the presence of adsorbed antibody on the normal neutrophil which is carried through the purification procedure.

Fibronectin failed to opsonise NTHI, in contrast to its established enhancement of staphylococcal opsonisation (Proctor et al., 1982) which we confirmed with our material. Tuftsin promoted phagocytosis but did not induce chemiluminescence. Quantitation of phagocytosis by electronmicroscopy is difficult and these findings must be regarded as qualitative. However, the failure of the phagosome to vacuolate with tuftsin is further evidence of a close connection between vacuole formation and the burst of oxidative metabolism which occurs during phagocytosis (Segal et al., 1982). 
Until recently, it has been possible to raise the serum IgG level in patients with severe hypogammaglobulinaemia by only about $200 \mathrm{mg} / 100 \mathrm{ml}$ by intramuscular gammaglobulin injections. However, it is now possible to raise it to well within the normal range with intravenous IgG concentrates, and the data shown here suggest that such treatment may have an advantage in eliminating non-typable $H$. influenzae from the respiratory system in these patients. A small trial comparing intramuscular and intravenous treatment supports this prediction (So et al., 1984).

We thank Mrs B. Dent for typing this manuscript.

\section{REFERENCES}

Asherson G L, Webster A D B 1980 Diagnosis and treatment of immunodeficiency diseases. Blackwell Scientific Publications, Oxford.

Horwitz M A 1980 The roles of the Fc and C3 receptors in the phagocytosis and killing of bacteria by human phagocytes. Journal of Reticuloendothelial Society. 28 Suppl:17-26.

Martin A, Lachmann P J 1977 Haemolytic assays in agarose plates for components of the classical complement pathway: Interference by the alternative pathway. Clinical and Experimental Immunology 27:13-22.

Medical Research Council Special Report Series 1971 310: Hypogammaglobulinaemia in the United Kingdom. HMSO, London.

Musher D M, Hague-Park M, Baughn R E, Wallace R J, Cowley B 1983a Opsonizing and bactericidal effects of normal human serum on nontypable Haemophilus influenzae. Infection and Immunity 39:297-304.

Musher D M, Kubitscher K R, Crennan J, Baughn R E $1983 b$ Pneumonia and acute febrile tracheobronchitis due to Haemophilus influenzae. Annals of Internal Medicine 99:444-450.

Proctor R A, Prendergast E, Mosher D F 1982 Fibronectin mediates attachment of Staphylococcus aureus to human neutrophils. Blood 59:681-687.

Segal A W, Harper A, Garcia R, Jones O T G, Cross A R, Geison M 1982 The nature and function of the microbicidal oxidase system of neutrophils. In: Rossi F, Patriarca P (eds) Biochemistry and function of phagocytes. Plenum Press, New York, pp 401-407.

So A, Brenner M K, Hill I D, Asherson G L, Webster A D B 1984 Intravenous gammaglobulin therapy in patients with hypogammaglobulinaemia. British Medical Journal 289:1177-1178.

Thompson R A 1981 Techniques in clinical immunology, 2nd edn. Blackwell Scientific Publications, Oxford.

Tully J G, Taylor-Robinson D, Rose D L, Furr P M, Hawkins D 1983 Evaluation of culture media for the recovery of Mycoplasma hominis from the human urogenital tract. Sexually Transmitted Diseases 10:256-260.

Wallace R J, Musher D M, Septimus E J, McGowan J E, Quinones F J, Wiss K, Vance P H, Trier P A 1981 Haemophilus influenzae infections in adults: characterization of strains by serotypes, biotypes and $\beta$-lactamase production. Journal of Infectious Diseases 144:101-106. 